\title{
Determination of Heavy Metals in Industrial Waste Waters of Tirupati Region, Andhra Pradesh
}

\author{
Putaka Ramesh $^{1}$, T. Damodhram ${ }^{2}$ \\ Department of Environmental Sciences, S. V. University, Tirupati, Andhra Pradesh - 517502
}

\begin{abstract}
Industrial waste waters collected from three industrial sites in and around Tirupati were determined for knowing the concentrations of heavy metals in Industrial region. Industrial waste waters were collected and studied for two years on a bimonthly basis (Jan 2014 - Dec 2015). The present research work deals with the study of six heavy metals (Cd, $\mathrm{Zn}, \mathrm{Pb}, \mathrm{Cu}, \mathrm{Cr}$ and $\mathrm{Fe}$ ). The analysis is performed using AAS (Perkin-Elmer, 2380). Results indicated that Cd ranged between 0.04 to $1.2 \mathrm{mg} / \mathrm{L}$, in all the sites which are above the permissible limits. The maximum concentration of $P b$ is $2.81 \mathrm{mg} / \mathrm{L}$ has been observed at Karakambadi industrial site. copper ranged from 0.41 to $2.98 \mathrm{mg} / \mathrm{L}$ and the average Cr ranged 1.16 to $2.86 \mathrm{mg} / \mathrm{L}$ in 2014 and 2015 . The results showed that the concentration levels are above the permissible limits in all the sampling sites. Iron ranged between $0.3 \mathrm{mg} / \mathrm{L} \mathrm{to} 4.8 \mathrm{mg} / \mathrm{L}$. The concentration of $\mathrm{Fe}$ in the industrial effluent was within the permissible limit except Renigunta Industrial waste water. The study has shown that almost all the heavy metals are at higher levels than the prescribed limits. Hence proper treatment methods are needed for waste water treatment. Some large scale industries have their own effluent treatment plants, but small scale industries are not following the guidelines prescribed for the industrial effluents.
\end{abstract}

Keywords: Heavy metals, Industrial waste water, $\mathrm{AAS}, \mathrm{Cd}, \mathrm{Pb}, \mathrm{Zn}, \mathrm{Cr}$

\section{Introduction}

Industrial Waste water is one of the important source of pollutants leading to the pollution of the water environment. During the last century large amounts of industrial wastewater was discharged into rivers, lakes and coastal areas. This has resulted in serious pollution problem in the water environment and caused negative effects to the ecosystem and human life. These wastes often contain a wide range of contaminants such as petroleum hydrocarbons, chlorinated hydrocarbons, heavy metals, various acids, alkalis, dyes and other chemicals which greatly change the physico-chemical properties of water. All these chemicals are quite harmful or even fatally toxic to the aquatic ecosystem [1-3]. The problem of environmental pollution on account of essential industrial growth is, practical terms, the problem of disposal of industrial water, whether solid, liquid or gaseous. All three types of wastes have the potentially of ultimately polluting water [4-5]

Effluents from textile, leather, tannery, electroplating, galvanizing, pigment and dyes, metallurgical and paint industries and other metal processing and refining operations at small and large-scale sector contain considerable amounts of toxic metal ions [6]. Today most of the rivers receive millions of liters of sewage, domestic waste and industrial effluents containing varying in characteristics from simple nutrient to highly toxic substances [7]. India has failed in waste management strategies adopted to keep pace with the industrial growth and urbanization. That impact on Indian economy holds a double edged sword of economic growth and ecosystem collapse [8]

Heavy metals are not biodegradable so they accumulate in primary organs in the body and over time begin to fester, leading to various symptoms of diseases[9] Thus, untreated or incompletely treated textile effluent can be harmful to both aquatic and terrestrial life by adversely affecting on the natural ecosystem and long term health effects. The main objectives of the present study were to determine the concentrations of various heavy metals present in the sampling sites.

\section{Methodology}

\section{Study Area}

The study was carried out at Tirupati urban industrial area which is one of the most rapidly developing and polluted industrial area of Tirupati. The industrial area is spread over 863.18 hectares of land consisting of about 600 large and medium scale industries like engineering units, steel processing industries, chemical units, paints, pharmaceutical units, textile industries and battery industries etc. The study area lies between latitude $19^{\circ} 3^{\prime} 39^{\prime \prime} \mathrm{N}$ longitudes $73^{\circ} 6^{\prime} 57^{\prime \prime} \mathrm{E}$ Water from these industries is continuously disposed off into soil. Populations around these areas are under risk of environmental pollution.

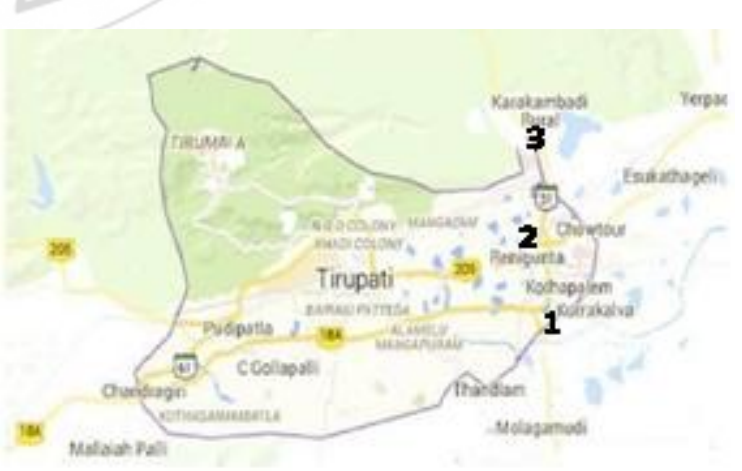

Figure: Map of the study area- Tirupati

\section{Industrial Effluent Sampling}

The industrial effluent samples were collected randomly on bimonthly basis in polyethylene bottles for a period of 2 years from different industrial sites like, Gajulamandyam industrial area, Renigunta industrial area and Karakambadi industrial area of Tirupati. The samples were collected from 


\section{International Journal of Science and Research (IJSR) \\ ISSN (Online): 2319-7064 \\ Index Copernicus Value (2013): 6.14 | Impact Factor (2015): 6.391}

January 2014 to December 2015. The sample container bottles were thoroughly cleaned with hydrochloric acid, cleaned with tap water to render free of acid, washed with distilled water twice, again rinsed with the water sample to be collected and then filled up the bottles and immediately transported to the laboratory for Analysis. A total of six elements $(\mathrm{Cd}, \mathrm{Zn}, \mathrm{Pb}, \mathrm{Cu}, \mathrm{Cr}$ and $\mathrm{Fe})$ were determined by using AAS (Perkin-Elmer, 2380).

\section{Results and Discussion}

The concentration levels of six heavy metals in industrial region of Tirupati, Chittoor district during the study period 2014-2015, the results are summarized and discussed below.

\section{Cadmium}

During the study period the cadmium average levels at three sites in the two years on bimonthly basis were ranged between 0.04 to $1.2 \mathrm{mg} / \mathrm{L}$, The concentration of $\mathrm{Cd}$ in all the sites are excess when compared to the permissible limit of Indian standards $(0.01 \mathrm{mg} / \mathrm{L})$ for effluents discharge causing toxic to the environment [10] [11]

\section{Zinc}

Zinc ranged from 1.02-7.22 $\mathrm{mg} / \mathrm{L}$, the average value of zinc at Gajulamandyam site is $6.701 \mathrm{mg} / \mathrm{L}$ in 2014 and $6.92 \mathrm{mg} / \mathrm{L}$ in 2015, at Renigunta Industrial site in 2014 is 7.11- 7.04 $\mathrm{mg} / \mathrm{L}$ in 2015 , at Karakmbadi Industrial site in 2014 is 1.28 $1.45 \mathrm{mg} / \mathrm{L}$ in 2015 . The occurrence of several folds higher $\mathrm{Zn}$ concentration in downstream was attributed to the greatest frequency of nearby sources like hazardous waste sites, industrial areas such as lead smelters and the emission of industrial effluents through the transmission of iron pipes [12]

\section{Lead}

During the study period lead concentration levels in the period of 2014 to 2015 ranged from $0.04 \mathrm{mg} / \mathrm{L}$ to $2.81 \mathrm{mg} / \mathrm{L}$. The maximum concentration of Lead has been observed at Karakambadi indusrial site $2.81 \mathrm{mg} / \mathrm{L}$. The maximum acceptable limit for Lead as per IS: 10500 and WHO guidelines is $0.1 \mathrm{mg} / \mathrm{L}$. However the observed concentration levels of Lead in the study area are higher than the permissible limits specified in the IS: 10500 and WHO guidelines except Gajulamandyam industrial site. A major source of $\mathrm{Pb}$ was probably the use of leaded petrol and battery industrial effluents [13]

\section{Copper}

In the present investigation the copper ranged from 0.41 to $2.98 \mathrm{mg} / \mathrm{L}$, the average values of copper is $0.811 \mathrm{mg} / \mathrm{L}$ in 2014 and $0.875 \mathrm{mg} / \mathrm{L}$ in 2015 at Gajualamandyam Industrial site, $2.611 \mathrm{mg} / \mathrm{L}$ in 2014 and $2.828 \mathrm{mg} / \mathrm{L}$ in 2015 at Renigunta Industrial site, at Karakambadi Industrial area $0.285 \mathrm{mg} / \mathrm{L}$ in 2014 and $0.336 \mathrm{mg} / \mathrm{L}$ in 2015 . This could be attributed to the reason of anthropogenic activities and industrial effluent released without treatment. Similar findings were reported [14-16]

\section{Chromium}

During the study period the average ranged 1.16 to 2.86 $\mathrm{mg} / \mathrm{L}$ of $\mathrm{Cr}$ in 204 and 2015. This was above the maximum tolerable level of Indian standards. Chromium is considered to be one of the most detrimental elements to the environment. In all the study sites in overall study period $\mathrm{Cr}$ was above the maximum acceptable limit for Chromium as per IS: 10500 is $0.05 \mathrm{mg} / \mathrm{L}$ and maximum acceptable limit as per World Health Organization is $0.05 \mathrm{mg} / \mathrm{L}[17]$

\section{Iron}

The average values of Iron values are $0.496 \mathrm{mg} / \mathrm{L}$ in 2014 and $0.513 \mathrm{mg} / \mathrm{L}$ in 2015 at Gajulamandyam Industrial site, $4.65 \mathrm{mg} / \mathrm{Lin} 2014$ and $4.71 \mathrm{mg} / \mathrm{L} 2015$ at Renigunta industrial site and karakambadi industrial site, $0.41 \mathrm{mg} / \mathrm{L}$ in 2014 and $0.42 \mathrm{mg} / \mathrm{Lin} 2015$ respectively. Iron ranged between $0.3 \mathrm{mg} / \mathrm{L}$ to $4.8 \mathrm{mg} / \mathrm{L}$. The concentration of $\mathrm{Fe}$ in the industrial effluent was within the permissible limit except Renigunta Industrial waste water. The presence of excess iron in water imparts the taste and it also promotes growth of iron bacteria that hasten rusting process of all the ferrous metals that come in contact with the water [18-20]

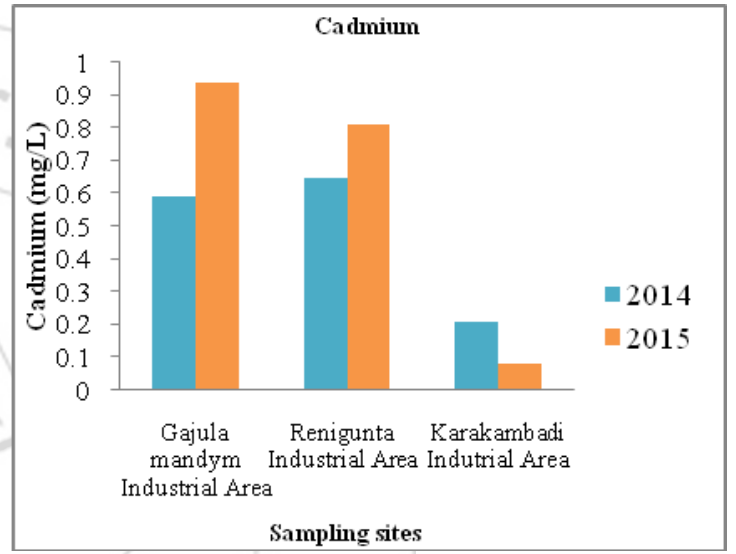

Figure 2: Average concentration of cadmium in three locations during 2014 and 2015

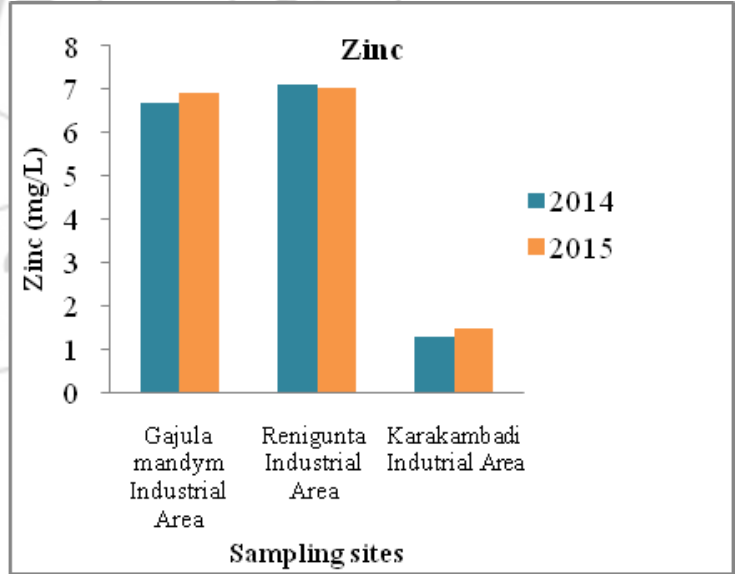

Figure 3: Average concentration of zinc in three locations during 2014 and 2015 
International Journal of Science and Research (IJSR)

ISSN (Online): 2319-7064

Index Copernicus Value (2013): 6.14 | Impact Factor (2015): 6.391

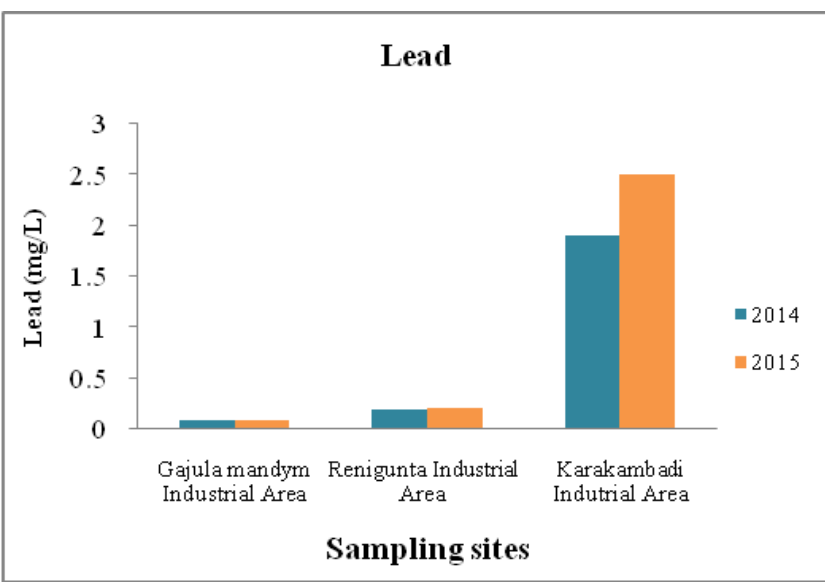

Figure 4: Average concentration of lead in three locations during 2014 and 2015

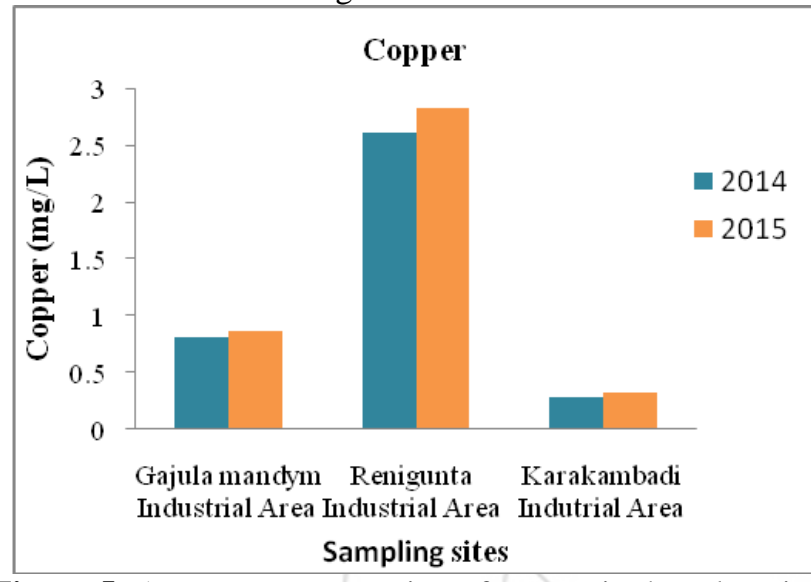

Figure 5: Average concentration of copper in three locations during 2014 and 2015

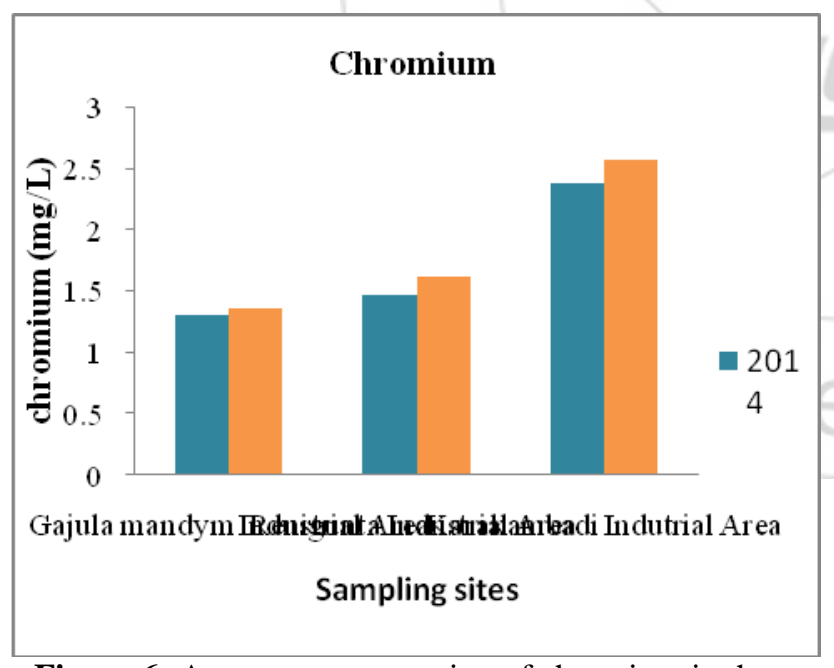

Figure 6: Average concentration of chromium in three locations during 2014 and 2015

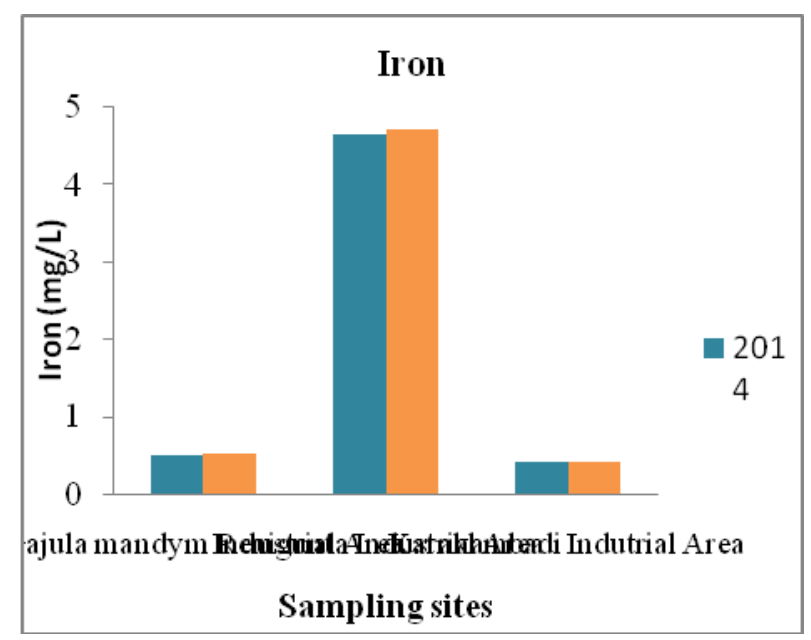

Figure 7: Iron levels from three locations of 2014 and 2015 in month by Month

\section{Conclusion}

The analysis of wastewater for heavy metal contamination is an important step in ensuring human and environmental health. Excess levels of heavy metals might cause several short term and long term health effects to the human beings. The present study is focused on determination of six heavy metals like Cadmium (Cd), Zinc ( $\mathrm{Zn})$ Lead ( $\mathrm{Pb}$ ), Copper $(\mathrm{Cu})$, Chromium $(\mathrm{Cr})$ and Iron $(\mathrm{Fe})$ in Tirupati Industrial Region, Andhra Pradesh. In three study areas during the study period above all the heavy metals in above the permissible set by the Indian Standards. This study reveals that waste waters from industrial sites were highly polluted; there is urgent need to follow adequate effluent treatment methods before their discharge to surface water for reducing their potential environmental hazards. Strict environmental laws become imperative so as to control this stress.

\section{References}

[1] Aghor, Chemicals make Thane creek the worst polluted water body. Daily DNA. August 14, 2007. Mumbai, India

[2] D. Patil, 'A lot's fishy about our creek and lake fish'. Daily Times of India. March 22, 2009. Mumbai, India

[3] Kumar, A., 1996, Impact of industrial pollution on the popu-lation status of endangered Gangetic dolphin (Platanista gangetica) in the River Ganga in Bihar, India. Pol. Arch. Hy-drobiol., 18(4), 469-476

[4] S. C. Barman, S.K. Sahu, S.K. Bhargava and C. Chatterjee, 2000. Bulletin of Environmental and Contamination Toxicology, vol. 64, pp. 489-496

[5] G.C. Kisku, S.C. Barman and S.K. Bhargava. 2000. Journal of Water, Air, and Soil Pollution, vol. 120, pp. 121137.

[6] Ahluwalia, S. S. and Goyal, D. 2007. Microbial and plant derived biomass for removal of heavy metals from wastewater. Bioresource Technology, 98, 98-2243

[7] Nivruti T. Nirgude, Sanjay Shukla and A. Venkatachalam. 2013, physico- chemical analysis of some industrial effluents from vapi industrial area, 


\section{International Journal of Science and Research (IJSR) \\ ISSN (Online): 2319-7064}

Index Copernicus Value (2013): 6.14 | Impact Factor (2015): 6.391

Gujarat, India, Vol. 6, No.1, ISSN: 0974-1496, Pp. 6872.

[8] Priyanka Dhingra, Yashwant Singh, Manish Kumar, Hitesh Nagar, Karan Singh, Laxmi Narayan Meena. 2015.

Study on Physico - Chemical Parameters of Waste Water Effluents from Industrial areas of Jaipur, Rajasthan, India. International Journal of Innovative Science, Engineering \& Technology, Vol. 2 Issue 5, $2348-7968$

[9] Siyanbola T O, Ajanaku K O, James O O, Olugbuyiro J A O, JAdekoya J O. 2011. Physico- Chemical Characteristics of Industrial Effluents in Lagos State,Nigeria. G. J. P\& A Sc and Tech, 01: 49-54

[10] Morrison, G. Fatoki, O. Linder, S. Lundehn, C. 2004. Determination of heavy metal concentrations and metal fingerprints of sewage sludge from Eastern Cape Province South Africa by ICP-MS and LA-ICP-MS. Water Air Soil Poll., 152, 111-127

[11] Usha Damodhar and Vikram Reddy M, 2012. Assessment of trace metal pollution of water and sediment of river gadilam (cuddalore, south east coast of India) receiving sugar industry effluents .Continental J. Environmental Sciences.6 (3), 8-24

[12] Pawlowski, B. Krawczyk, J. Bala, P. 2013. The premature deterioration of Zinc-coated steel pipes in water distribution system. Inter. J. Mater. Mech. Eng, 2, 43-47.

[13] Children at the End of the Leaded Petrol Era.Abridged Report $2009 . \quad$ Available online:http://www.anglogold.com/subwebs/Information ForInvestors/Reports09/AnnualReport09/f/AGA_ABRI DGED09.pdf (accessed on 30 December 2013

[14] Romo-Kroger C.M, Morales J.R, Dinator M.I \& Llona F, 1994. Heavy metals in the atmosphere coming from a copper smelter in Chile. Atmos. Environ., 28, 705-711

[15] Wu M.M, Chiou H.Y, Wang T.W, Hsueh Y.M, Wang I.H, Chen C.J \& Lee T.C, 2001. Association of blood arsenic levels with increased reactive oxidants and decreased antioxidant capacity in human population of northeastern Taiwan. Environ. Health Perspective, 109, 1011-1017.

[16] Rafiquel Islam, Jannat Al Foisa, Hasanuzzaman, Musrat Rahman, Laisa Ahmed Lisa and Dipak Kumar Pau. 2016. Pollution assessment and heavy metal determination by AAS in waste water collected from Kushtia industrial zone in Bangladesh. African Journal of Environmental Science and Technology, Vol.10 (1), pp. $9-17$

[17] O. Venkata Subba Raju, P.M.N. Prasad, V. Varalakshmi and Y.V.Rami Reddy.2014. Determination Of Heavy Metals In Ground Water By Icp-Oes In Selected Coastal Area Of Spsr Nellore District, Andhra Pradesh,India. International Journal of Innovative Research in Science, Engineering and Technology, Vol. 3, Issue 2, 2319-8753

[18] Chukwu, H.I. Mustapha, and H.B. Abdul Gafar. 2008. The effect of Minna Abattoir Waste on Surface Water Quality I. Environ

[19]Rajappa, B., Manjappa, S and Puttaiah, E.T. 2010. Monitoring of heavy metal concentration in groundwater
HakinakaTaluk, India. Contemporary Engineering Sciences, 3(4):183-190

[20] Bhaskar, C.V., Kumar, K \& Nagendrappa, G. 2010. Assessment of heavy metals in water samples of certain locations situated around Tumkur, Karnataka

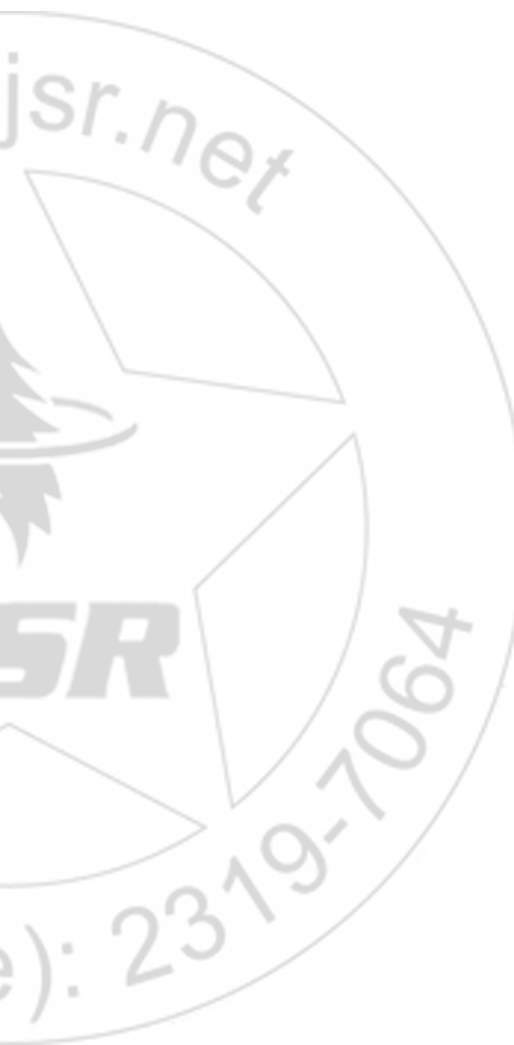

